\title{
Swift and the Sacramental Test: A New Attribution from 1719
}

On 1 July 1719, the Duke of Bolton entered the House of Lords to deliver the 'speech from the throne' that by convention announced the legislative priorities for the coming parliamentary session. A cluster of Irish peers and their sons were in attendance, bearing the sword of state and the cap of maintenance that accompanied the viceroy on such ceremonial occasions. Once the Commons had been summoned to the bar by the Gentleman Usher of the Black Rod, Bolton read a statement that antagonised the overwhelming majority of peers and MPs assembled there. He began by warning that the Jacobite invasion attempt of that spring demonstrated the continuing threat to both Britain and Ireland from domestic subversion and foreign aggression. The word that summed up that threat was 'popery'. The lord lieutenant then urged Ireland's Protestants to unite in the face of their common enemy; it was the king's desire that some effective method be found 'to render the Protestant Dissenters more useful and capable of serving his Majesty, and supporting the Protestant Interest'. ${ }^{1}$ This apparently innocuous phrase proclaimed the government's intention to abolish the sacramental test that restricted public office to members of the established church. A greatly diluted bill 'For exempting the Protestant Dissenters of this kingdom from certain penalties to which they are now subject' was returned from England three months later. When the measure was sent to the Lords, on 16 October, copies of an anonymous pamphlet were distributed at the doors of both houses, entitled Some Considerations upon the Late Attempt to Repeal the Test Act ... By a Person of Quality. ${ }^{2}$ The pamphlet has escaped the notice of critics and historians, but its style and the arguments employed by the author clearly identify him as the Dean of St Patrick's, Jonathan Swift. ${ }^{3}$

Ten years ago I quoted a passage from Some Considerations upon the Late Attempt in a general historical survey of eighteenth-century Ireland. About two-thirds of the way through the pamphlet, the author abruptly remarks that the kingdom of Ireland is 'very different from ... any other under the Sun' (p. 16). This was a recurrent theme in Swift's political writings of the 1720s. In 1729, for example, he wrote despairingly of 'the singular condition of this Country different from all others upon the face of the Earth'. ${ }^{4}$ The first example of Irish exceptionalism offered by the author was also a longstanding object of Swift's resentment: the recent custom of granting Irish bishoprics to Englishmen who served as chaplains to lord lieutenants, 'except where some Prelate from thence will condescend to come over in order to instruct and civilise

\footnotetext{
${ }^{1}$ Journals of the House of Lords (8 vols., Dublin, 1779-1800), II, 603-4.

${ }^{2}$ Some Considerations upon the Late Attempt to Repeal the Test Act. Humbly offered to the Dissenters, as well as to those Gentlemen of the Established Church, who were of Opinion that the said Act ought to be Repealed. By a Person of Quality ('London' [Dublin], 1719). Page numbers will be cited in the main text.

${ }^{3}$ Ian McBride, Eighteenth-Century Ireland: The Isle of Slaves (Dublin, 2009), p. 294.

4 'A Letter to the Archbishop of Dublin, concerning the Weavers' (1729) in David Hayton and Adam Rounce (eds.), The Cambridge Works of Jonathan Swift, vol. XIII. Irish Political Writings after 1725: A Modest Proposal and Other Works (Cambridge, 2018), p. 100. Similarly, the general reversion of Irish offices to English favourites prompted the Drapier to comment that 'the Kingdom of Ireland is distinguished from all other Nations upon Earth': Herbert Davis (ed.), The Drapier's Letters to the People of Ireland (2 ${ }^{\text {nd }}$ edn, Oxford, 1965), p. 73.
} 
$u s^{\prime}$ (p. 16). ${ }^{5}$ That jibe was directed at John Evans, translated from Bangor to the wealthy see of Meath in 1716, and his ally William Nicolson, promoted from Carlisle to Derry two years later. ${ }^{6}$ The anonymous author identified these two outsiders (Evans was a Welshman, Nicolson English), as enemies to the constitutional rights of Ireland:

\begin{abstract}
The Words Province, Colony, Plantation, Conquest, and depending Kingdom are ever in these Mens Mouths, without knowing that the universal Opinion of Civilians is against them, and without being able to apprehend that one Kingdom does not lose its Legislature, by being under the same Administration with another. For if Slavery were to be defined by the strictest Rules of Logick; there could be no other Notion of it, than that of being governed by Laws, to which we do not Consent (p. 17).
\end{abstract}

When I first came across this ringing affirmation of Ireland's independence I thought it was instantly recognisable as Jonathan Swift's. The lapidary formulation of slavery, the use of the term 'depending kingdom' and the reference to the 'Opinion of Civilians' - all would be repeated in the Drapier's Letters in 1724. As I seek to demonstrate below, this combination is unique to Swift. But specialists will expect a comprehensive examination of the pamphlet before they accept that the 'Person of Quality' was the Dean of St Patrick's. In this article I aim to establish the case for attributing the work to Swift, and to offer an interpretation of its significance. This exercise involves the usual contextual method of intellectual history, a reconstruction of the parliamentary politicking of 1719 , and a bibliographical foray into the world of Dublin print culture during the reign of George I. The evidence presented will include extensive verbal parallels between Some Considerations upon the Late Attempt and other tracts generally acknowledged to be written by Swift's; the results of a systematic survey of pamphlets dealing with the sacramental test; an examination of the correspondence of Swift and of other political players in the Irish debates of 1719; and a reading of the polemical strategy adopted by the Person of Quality.

Since the following discussion is necessarily detailed, it might help to declare two simple points in advance. The first is that, with only one exception that I can find, no other tract written in defence of the sacramental test connected the maintenance of the Church of Ireland's monopoly over civil and military office with the explosive issue of Ireland's legislative independence. To do so was risky: it was prudent for Irish politicians to pick one fight at a time with the imperial government in London. William Tisdall, an erstwhile friend of Swift and the other principal anti-Presbyterian writer in Ireland, steered clear of the constitutional controversy, as did the mostly anonymous pamphleteers who countered the Presbyterian offensive of 1732-33. The

\footnotetext{
5 'On the Bill for the Clergy's Residing on their Livings' (1732), which Swift left unpublished, features a similar attack on English-born bishops, who 'have condescended to leave their native country, and come over hither to be bishops, merely to promote Christianity among us': The Prose Writings of Jonathan Swift, ed. Herbert Davis et al., 16 vols. (Oxford, 1939-74), XII, 180.

${ }^{6}$ For the resultant tensions see Patrick McNally, “'Irish and English Interests': National Conflict within the Church of Ireland Episcopate in the Reign of George I', IHS, XXIX, no. 115 (1995), 295-314.
} 
only other printed work that combined these grievances was Swift's Letter concerning the Sacramental Test (1709). This much-reprinted pamphlet was the Dean's first published comment on Irish politics. It incorporated a ferocious attack on Alan Brodrick, then speaker of the Irish Commons and later, raised to the peerage as Viscount Midleton, the Lord Chancellor. In the 1690s Brodrick had been a champion of Irish parliamentary rights; but recently he had been in London lobbying on behalf of the Irish Presbyterians - or so Swift believed. There were rumours that the ministry intended to circumvent Irish opposition by passing an act at Westminster repealing the sacramental test. This constituted English interference in 'a matter purely National', and Swift accordingly reprimanded Brodrick, 'formerly the most Zealous of all Men against the Injustice of binding a Nation by Laws, to which they do not consent'. ${ }^{7}$ It is no coincidence that, ten years later, the Person of Quality would make an obscure dig at Midleton for his pusillanimity in the defence of Ireland's independence (see Appendix II). My second preliminary observation is that contemporaries naturally speculated about the identity of the Person of Quality and, as Bishop Nicolson reported, they believed that the author was either Archbishop King of Dublin 'or his Dean' 8

Some Considerations upon the Late Attempt is the most substantial and significant work to be attributed to Swift since Herbert Davis's fourteen-volume Prose Writings of Jonathan Swift was completed half a century ago. Among other things, it reminds us of the sheer volume of Swift's Irish polemics, and invites us to re-examine other works for his fingerprints. ${ }^{9}$ Like the Letter concerning the Sacramental Test, it marked a turning-point in Swift's political evolution. In 1709 it had been a threat to the test that provoked Swift's breach with the Whig patrons in London whom he had solicited for financial assistance for the Church of Ireland and for the advancement of his own clerical career. Now, ten years later, Some Considerations upon the Late Attempt signalled his acknowledgement that the Tory party, in Ireland at any rate, was no longer an independent political force. The pamphlet announced Swift's desire to make peace with the Whigs in Dublin, or at least those like Archbishop King who were committed to the 'Irish interest', and in this respect it prefigured the patriot campaign against Wood's halfpence.

\section{Irish Parliamentary Politics in $\mathbf{1 7 1 9}$}

Some Considerations upon the Late Attempt deals with two distinct grievances that, for at least some high churchmen, became fused during the autumn of 1719. The first concerned the gradual reduction of the Irish parliament to a strictly subordinate position within the British composite monarchy. Since the revolution of 1688 there had been several jurisdictional clashes

\footnotetext{
7 [Jonathan Swift], A Letter from a Member of the House of Commons in Ireland to a Member of the House of Commons in England concerning the Sacramental Test (London, 1709), p. 5.

${ }^{8}$ Nicolson to Wake, 17 Oct. 1719, Christ Church Oxford, Wake MS XIII, 117.

${ }^{9}$ Among others, these should include ESTC T107306, T167835, T150043, T166406.
} 
between the Westminster parliament - now a regular, permanent instrument of government and its junior and comparatively feeble counterpart in Dublin. Their histories were quite different. When the Irish parliament assembled in 1692 it was after a hiatus of 26 years, and its members improvised for themselves a set of parliamentary traditions and procedures, drawing partly on the fragmentary records of their predecessors and partly on English practice. The Irish legislature was monopolized by a settler elite which regarded Catholics - four-fifths of the population - as enemies; it was also apprehensive about the growing demographic, economic and political strength of the 'Scots' Presbyterians in Ulster. At Westminster, meanwhile, regular parliamentary sessions enabled MPs to scrutinise government spending for the first time and to debate and shape ministerial policy. Simultaneously, they began to envisage England's empire as a single unit in which kingdoms and colonies must be subordinated in order to serve the commercial as well as geopolitical interests of the mother country. ${ }^{10}$ The result was a new phase of constitutional innovation that would culminate in the passage of the Declaratory Act of 1720, by which the Westminster parliament affirmed its right to legislate for Ireland 'in all cases whatsoever'. ${ }^{11}$

The immediate issue for Irish patriots in 1719 was not legislative supremacy but the appellate jurisdiction of the Irish House of Lords, or what contemporaries called the dernier resort. The case of Annesley v. Sherlock (1717-19) was the latest example of an alarming tendency for the British Lords to overturn judgments made by their Irish counterparts, thus assuming to themselves the authority of the highest court of appeal in Irish property disputes. In January 1719 the British Lords ruled in favour of Maurice Annesley and ordered that the High Sheriff of Kildare be taken into custody for permitting Hester Sherlock to remain in possession of the lands in dispute. The Irish Lords responded by examining the three senior law barons who attempted to enforce the British judgement. Led by Archbishops King and Synge, they resolved that the three barons be taken into custody on the ground that each was 'a Betrayer of his Majesty's Prerogative, and the undoubted antient Rights and Privileges of this House, and of the Rights and Liberties of the Subjects of this Kingdom'. ${ }^{12}$

One feature of these debates was that the five English-born bishops, who consistently upheld the 'imperial' view, found themselves isolated. They faced the hostility of their fellow peers and the abuse of the Dublin mob. Their response was to lobby Archbishop William Wake to use his influence to secure a formal declaration of Ireland's constitutional inferiority. Bishop Nicolson of Derry protested that 'instead of parting with our old one, we ought to have a new Test, requiring all officers, civil and military, solemnly to recognize the dependence of this

${ }^{10}$ Ian McBride, 'The Case of Ireland (1698) in Context: William Molyneux and his Critics', PRIA, vol. 118C (2018), 201-30.

11 Patrick Kelly, 'Ireland and the Glorious Revolution: From Kingdom to Colony', in Robert Beddard (ed.), The Revolutions of 1688 (Oxford, 1991), pp. 163-90; David Hayton, 'Constitutional Experiments and Political Expediency, 1689-1725', in Steven G. Ellis and Sarah Barber (eds), Conquest and Union: Fashioning a British State, 1485-1725 (London, 1995), pp. 276-305.

12 JHLI, II, 627. For a discussion see Martin Stephen Flaherty, 'The Empire Strikes Back: Annesley v. Sherlock and the Triumph of Imperial Parliamentary Supremacy', Columbia Law Review, vol. 87, no. 3 (Apr., 1987), 593622. 
kingdom on the imperial crown of Great Britain'. ${ }^{13}$ Evans was particularly vituperative. In August he warned that the Irish patriots aimed at 'Independency' and would not be silenced unless a bill were prepared in England 'to fix us on Just Foundations'. ${ }^{14}$

The five 'English' bishops were also at loggerheads with their Irish counterparts over the other great issue of the 1719 parliamentary session, the attempt to pass a measure of relief for Irish Dissenters. The story of Bolton's efforts to improve the legal status of Dissenters is one of English miscalculation, Irish sabotage and eventual anti-climax. It begins with the joint ministry of Stanhope and Sunderland, brought to power in the aftermath of the Whig schism of I717. Ideological impulses and short-term tactical expedients combined to make this the most anti-clerical government of the eighteenth century. In January 1719 the StanhopeSunderland ministry repealed the Occasional Conformity and Schism Acts in England and Wales. ${ }^{15}$ Unable to make further inroads against established religion at home, the ministry opted to consolidate their support base among English Dissenters by lifting the legal restrictions on their Irish brethren. The government seems to have believed it could obtain an 'entire repeal of the sacramental test' across the water. ${ }^{16}$ When Lord Chancellor Midleton cautioned that the most Irish parliamentarians would contemplate was the admission of non-conformists to the militia and lower army commissions, he was told that repeal could not fail 'if heartily espoused in Britain and supported and countenanced by those in his Majestyes service in Ireland': in other words the ministers were determined to force the measure through the Irish legislature. ${ }^{17}$

Whitehall underestimated the hatred of Ulster Presbyterians nursed by Irish churchmen. It was never likely that either house of the Irish legislature would be bullied into repealing the sacramental test. Bishop Evans of Meath reassured Wake that the Church of Ireland bishops were unanimously opposed to any dilution of the test; he was confident too of support from the temporal Lords and leading members of Commons. ${ }^{18}$ Bishop Nicolson declared that the more timid option of opening up militia commissions to Dissenters was also bound to fail because, even in Ulster, 'they have not one share in Fifty of the Land-Interest'. ${ }^{19}$ Sir Ralph Gore, the chancellor of exchequer, nevertheless proposed heads for a bill on 4 July, 'For rendering the Protestant Dissenters more useful and capable of supporting the Protestant interest of this

\footnotetext{
13 Nicolson to Wake, 1 Sept. 1719, Christ Church, Oxford, Wake MS XIII, 104.

14 Evans to Wake, 9 Aug. 1719, Christ Church, Oxford, Wake MS XIII, 101. See also Timothy Godwin (bishop of Kilmore) to Wake, 30 July 1719, Evans to Wake, 18 Sept. 1719, Evans to Wake, 31 Oct 1719, Godwin to Wake, 16 Jan. I720, Christ Church Oxford, Wake MS XIII, 95, 109, 119, 144.

15 G. M. Townend, 'Religious Radicalism and Conservatism in the Whig Party under George I: The Repeal of the Occasional Conformity and Schism Acts’, Parliamentary History, VII (1988), 24-44.

16 [Lord Midleton] to [Thomas Brodrick], 16 Aug. 1719, Surrey History Centre, Midleton Papers, MS 1248/4/156-159. I am grateful to David Hayton for a transcription of this and other documents from the Midleton archive.

17 Ibid.

18 Evans to Wake, 2 July 1719, Christ Church, Oxford, Wake MS XIII, 75.

${ }^{19}$ Nicolson to Wake, 2 July 1719, Christ Church, Oxford, Wake MS XIII, 74.
} 
kingdom'. This was an official or 'Court' measure. According to one of Wake's correspondents it not only guaranteed freedom of worship to Dissenters but permitted them to be 'Justices of $y^{e}$ peace officers of $y^{e}$ Militia \& to have Employments not exceeding $10011 \mathrm{p}[\mathrm{e}] \mathrm{r}$ an[num] salary, \& some Employments in $\mathrm{y}^{\mathrm{e}}$ Army'. ${ }^{20}$

With the scope of the government's ambitions unclear, and with signs of a furious backlash mounting in Dublin, an opposition faction in the Irish Commons now countered by drawing up its own draft bill for a bare toleration, entitled 'For exempting the Protestant Dissenters of this kingdom from certain penalties to which they are now subject'. (This was the measure eventually enacted as 6 George I c. 5, the Irish 'Toleration Act'.) Its sponsors were the Brodrick faction in the Commons, led by the Lord Chancellor's son, St John Brodrick. Belatedly, the County Antrim gentleman Clotworthy Upton scrambled to salvage some meaningful measures of relief. Two years earlier he had travelled to London with two Dissenting clergymen from Dublin, with the intention of getting a clause repealing the test inserted into an English bill. ${ }^{21}$ Now he pleaded for a few additional concessions legalising marriages performed by Dissenting ministers and giving their congregations the right to erect meeting-houses notwithstanding the restrictions some landlords placed in their leases. ${ }^{22}$ Upton's amendments were kicked out by around 200 votes to 20. The assault on the test was dead. All that remained was a minimal toleration of Protestant Dissenters on same terms granted in England in 1689; this was conceded, as Archbishop King expressed it, in order 'that it may stop their mouths for the future'. 23

The Toleration Act was a defeat for the Court and an insult to the Presbyterians. ${ }^{24}$ But in their hurry the Commons had omitted the requirement that any Protestant Dissenter taking advantage of the legislation should be obliged to subscribe a modified version of the Thirty-Nine Articles. ${ }^{25}$ Archbishop King was appalled. The Commons, he explained to Wake, had felt obliged 'to do something $\mathrm{w}^{\text {ch }}$ might be reckoned a complyance' with Bolton's speech from the throne. They had drawn up heads of a toleration bill 'in great haste', and forgotten to

\footnotetext{
20 'A Brief Account of Some Proceedings in ye Parliament of Ireland', 16 July 1719, Christ Church, Oxford, Wake MS XIII, 90.

${ }^{21}$ King to Wake, 6 May 1717, TCD MS 2534/160/181.

22 Thomas Lindsay to Wake, 15 July 1719, Evans to Wake, 16 July 1719, Nicolson to Wake, 16 July 1719, Christ Church, Oxford, Wake MS XIII, 87, 88, 89.

23 King to Wake 1 Aug 1719, Christ Church, Oxford, Wake MS XIII, 98.

${ }^{24}$ For the position of Protestant Dissenters see Ian McBride, 'Presbyterians in the Penal Era', Bullán, 1:2 (Autumn, 1994), pp. 73-86; David Hayton, 'Exclusion, Conformity and Parliamentary Representation: The Impact of the Sacramental Test on Irish Dissenting Politics', in Kevin Herlihy (ed.), The Politics of Irish Dissent 16501800 (Dublin, 1997), pp. 52-73. Also useful is Neal Garnham, 'The Establishment of a Statutory Militia in Ireland, 1692-1716: Legislative Processes and Protestant Mentalities', Historical Research, vol. 84, no. 224 (May 2011), 266-287.
}

25 Thomas Lindsay to Wake, 15 July 1719, Christ Church, Oxford, Wake MS XIII, 87. 
incorporate a profession of belief in the Thirty-Nine Articles or the doctrine of the Trinity. ${ }^{26}$ King rather hysterically claimed that Ireland now offered a wider measure of toleration than anywhere else in the world, offering legal protection for 'Jews, Turks, deist[s], Socinians and all the most wild and fanatick Sects' to attack the establishment. ${ }^{27}$

When Some Considerations upon the Late Attempt was 'plentifully dispers'd at ye Doors of both Houses' on 16 October the issue was no longer the exclusion of Presbyterians from political office, but rather the loosely formulated terms of the toleration bill, which seemed to encourage micro-groups such as the Arians and Socinians who rejected the orthodox doctrine of the Trinity. ${ }^{28}$ On 27 July King had introduced a toleration bill of his own devising in the House of Lords, reinstating the clauses omitted by the Commons. But the lord lieutenant resolved to stick to the bill framed by the Commons, and the five 'English' bishops - Evans, Nicolson, Godwin, Downes and Lambert - followed the Castle line, to the fury of King and the rest of the episcopal bench. The final vote in the Lords was 24:15 in favour of the Commons measure, now backed by the Court. A Dublin Castle official summarized the debate thus:

The Dissenters Bill was this day debated in the Committee of the House of Lords, and was vigorously opposed by the Arch Bishops of Dublin and Tuam, and other Spiritual Lords in almost every part of it, and the primate [Thomas Lindsay] concluded what he had to offer, by assuring their Lordships that Schism was a damnable Sin. Several of those Lords began their Speeches with great professions of a desire of some Toleration tho' not so ample a one, and concluded them with some sharp Invectives against the Dissenters. The objection most insisted on was that the Dissenters were not obliged by the Bill to Subscribe any of the 39 Articles and consequently that many persons of very extravagant persuasions would be entitled to the benefit of this Act, the nature of whose Religious Tenets the Government would not gain the least Assurance of, But others were of Opinion, that the Government would be sufficiently secured by the Oaths and Declarations of Allegiance which the Act requires. ${ }^{29}$

(It is worth noting that the oaths of allegiance included not only abjuration of the claims made by the Stuart dynasty to the throne of the three kingdoms, but the repudiation of the doctrine of transubstantiation, and so Catholics were unable to take it.)

The rearguard action against the toleration bill was couched in the language of schism, with the chaotic explosion of religious radicalism during the 1640s and 1650s as the obvious reference-point. This is clear from Archbishop Synge's speech, which survives in its entirety. Reminding the Lords that 'no less than 180 heterodox opinions' had surfaced during the English civil war, Synge predicted the re-emergence of heretical sects in Ireland, openly

\footnotetext{
${ }^{26}$ King to Wake, 1 Aug 1719, Christ Church, Oxford, Wake MS XIII, 98.

27 King to Southwell, 12 Nov. 1719, TCD MS 750/5/210-12.

28 The quotation is from Nicolson to Wake, 17 Oct. 1719, Christ Church, Oxford, Wake MS XIII, 117.

${ }^{29}$ Webster to Delafaye, 22 Oct. 1719, TNA, SP 63/378, f. 102r.
} 
preaching doctrines 'worse than those of heathens \& Mahometans' simply by presenting themselves as Dissenters. ${ }^{30}$ In this political context Some Considerations upon the Late Attempt to Repeal the Test Act appears to be misconceived. The project of repealing the test announced in Bolton's speech had been decisively defeated in July. And yet this was the scheme - of giving Presbyterians 'an equal share of Civil Power' - repudiated by the Person of Quality (p. 9). The new, if rather hypothetical, danger was that the bishops' courts would no longer have the power to prosecute those who publicly expressed heterodox views on the Trinity. It is possible, of course, that the Person of Quality had completed the main part of his text in July and felt it was still worth publishing in the altered circumstances of October. It is also possible that the author's object was simply to whip up hostility to Dissenters rather than to address the specific points of the legislative debate. ${ }^{31}$ To make better sense of Some Considerations, however, we need first to recognise that it incorporates an argument about the reorientation of party alignments in Ireland under conditions of heightened antagonism between the parliaments of Britain and Ireland.

\section{Some Considerations upon the Late Attempt: Arguments and Structure}

Three overlapping themes emerge from Some Considerations upon the Late Attempt. The first naturally concerns the danger posed to the established church by Protestant Dissenters. The reasons for excluding nonconformists from public office are presented in strikingly secular and abstract terms (pp. 3-7); but there follow a couple of pages of English historical examples from the Reformation and the seventeenth century, and two further pages relating to the alleged neutrality of Ulster Presbyterians during the Jacobite invasion scare of 1708. As we shall see shortly, these passages closely follow Swift's Letter concerning the Sacramental Test (1709) and they also anticipate his anti-repeal pamphlets of 1732-33. The overarching theme of the pamphlet's second half is unusual: from page 12 to 22 the author makes the novel assertion that Dissenters already have more access to political influence than the Tories, and he contends that it would be better policy to attempt to conciliate the latter than reward the former. This section also rehearses a series of patriotic grievances - the author's resentment at the designation of Ireland as a 'depending kingdom', the prevalence of absenteeism among the landed elite and the restrictions imposed by England on Irish trade and manufacturing. Above all the Person of Quality complains about the preferment of Englishmen to Irish ecclesiastical positions. In this respect, of course, he anticipates the famous injunction made in the Proposal

30 'The $\mathrm{L}^{\mathrm{d}}$ Archbishop of Tuam's speech on the toleration Bill Before the $\mathrm{L}^{\mathrm{rds}}$ Committees of the whole House', Christ Church, Oxford, Wake MSS XIII, 128/2 (enclosed in Synge to Wake, 19 Nov. 1719, ibid., 128/1).

31 There were no other pamphlets on the Dissenters bill, but two relevant items were reprinted in 1719. The first was a lengthy tract written against toleration by Bishop Tobias Pullen of Dromore in 1695, A Defence of the Answer to a Paper Intituled the Case of the Dissenting Protestants of Ireland, in Reference to a Bill of Indulgence (Dublin, 1695, repr. 1719). This argued that toleration would inevitably lead to the multiplication of sects but also included much standard anti-Presbyterian abuse. The other was The Representation of the General Assembly of the Kirk of Scotland, Presented on the First Day of June, 1703 (Dublin, 1719), a protest by Scottish Presbyterians against the toleration of Episcopalians reissued as a warning of how Presbyterians would behave when in power. 
for the Universal Use of Irish Manufacture that the Irish should burn everything that comes from England except their coal. That famous line is followed by the Juvenalian tag 'Non tanti Mitra est, non tanti Judicis ostrum' (A bishop's mitre is not worth so much, nor the purple robes of a judge). ${ }^{32}$

Neither the ecclesiastical nor the patriotic arguments employed by the Person of Quality were typical of Irish churchmen. But in order to evaluate the distinctiveness of this text we need to assemble a corpus of relevant material with which it might appropriately be compared. To begin with, I have searched the ESTC for Dublin publications between 1700 and 1735 with 'test', 'Dissenters' or 'Presbyterians' in their titles, discounting those that took the Presbyterian side and those that were reprints of English titles. The vast majority are from the years 173233 when there were parallel campaigns for repeal in Ireland and England. I have combined this list with titles accumulated from the relevant secondary sources. ${ }^{33}$ The results immediately reveal the outstanding importance of Swift in the propaganda directed against the political demands of the Presbyterians. There are 26 items in total (see Appendix I), of which eleven are generally agreed to be the work of the Dean of St Patrick's. I have not included poems, such as Swift's 'Brother Protestants and Fellow Christians', which was not printed as a separate item, or the spoof Reasons Humbly Offered to the Parliament of Ireland for Repealing the Sacramental Test \& $c$ which was published only in London in $1738 .{ }^{34}$ Nor have I included The Correspondent, which has material in issues 3-4 sometimes attributed to Swift, or works like The North Country-Man's Description of Christ's Church, Dublin, 'Signed: J. S.' (1733) which are anti-Presbyterian but not really about the test. ${ }^{35}$ Even if we widen the terms of our search to add four works by the Rev. William Tisdall of Belfast, which belong to a northern controversy over 'Presbyterian loyalty' but are not directly focused on the test, we will find that Swift was the author of more than a third of the total. ${ }^{36}$

\footnotetext{
32 [Jonathan Swift], A Proposal for the Universal Use of Irish Manufacture (Dublin, 1720), p. 6.

${ }^{33}$ William Monck Mason, The History and Antiquities of the Collegiate and Cathedral Church of St. Patrick, near Dublin (Dublin, 1820), pp. 387-90; J. S. Reid, History of the Presbyterian Church in Ireland (3rd edn., Belfast, 1867); III, 230-35; J. C. Beckett, Protestant Dissent in Ireland 1687-1780 (London, 1948), ch. 8; Phil Kilroy, Protestant Dissent in Ireland 1660-1714 (Cork, 1994), chs. 7-8; Ian McBride, 'Ulster Presbyterians and the Confessional State, 1689-1733', in D. G. Boyce and R. R. Eccleshall (eds.), Political Discourse in Early Modern Ireland (Macmillan, 2001), pp. 169-92.

${ }^{34}$ George Faulkner published the poem 'On the Words - Brother Protestants, and Fellow Christians, so familiarly used by the Advocates for the Repeal of the Test Act in Ireland, 1733' in 1735, in Poems on Several Occasions. By J. S, D.D, D.S.P.D. and again in volume II of The Works of J. S, D.D, D.S.P.D. Reasons Humbly Offered to the Parliament of Ireland for Repealing the Sacramental Test first appeared in Political Tracts. By the Author of Gulliver's Travels (2 vols., London, 1738), II, 257-70, dated 'Dublin, Nov. 1733'.
}

35 A full list of Swift's writings on the test would also include 'Some Few Thoughts concerning the Repeal of the Test', first printed by Deane Swift in the 1765 Works. The Royal Irish Academy contains a 24-page pamphlet dated 'Dublin November 1733' entitled An Enquiery [sic] into the Ministry of Presbyterians. ... In a Letter to S. Hollyday, Presbyterian Teacher. By the Rever'd Doctor, S.—_Dublin, 1733), but this is both too theological and too laborious to be Swift's work, and bears no resemblance to his anti-Presbyterian writings.

36 [William Tisdall], A Sample of True-Blew Presbyterian Loyalty (Dublin, 1709), [William Tisdall], The Conduct of the Dissenters of Ireland (Dublin, 1712); William Tisdall, A Seasonable Enquiry Into that Most Dangerous 
Comparing Some Considerations upon the Late Attempt with other pamphlets and handbills on the test enables us to distinguish more unconventional positions and emphases from those that were commonplace. The first noticeable feature is that the point of departure is a view of human vanity rather than any point of theological doctrine. The author reminds his readers that every state, even the Dutch Republic, restricts access to 'Civil Power' in favour of members of the established church. On the other hand all sectaries have endeavoured to propagate their own beliefs, since 'the fonder any Man is of his own Tenets, his Abhorrence must be greater in Proportion for the sentiments of those who differ from him' (p. 7). Swift would adopt the same approach in The Advantages Propos'd by Repealing the Sacramental Test (1732). The latter opens by noting that in all countries - even Holland - there is an established church, whose members have granted a monopoly of civil employments, but then remarks that 'whoever begins to think the National Worship is wrong, in any important Article of Practice or Belief, will, if he be serious, naturally have a Zeal to make as many Proselytes as he can'. ${ }^{37}$ This contention is certainly in keeping with Swift's wider outlook. Long ago Claude Rawson remarked that, from the Sentiments of a Church-of-England Man onwards, the primary function of established religion for Swift was to provide 'a pragmatic principle of cohesion, a simplifying and official restraint on the anarchic proclivities of the human mind'. Dissent was treated as a threat to public order rather than a spiritual danger. As Rawson put it, the whole question of religious uniformity is 'not only readily secularised, but psychologised'. ${ }^{38}$

The Person of Quality next illustrates his position with a brief historical survey of the religious upheavals that have taken place in England since the Reformation. It was very common for anti-Dissenter works to discuss the alleged responsibility of Presbyterians for the civil war and regicide. But no other advocate for the Irish test paused to censure Henry VIII, as Some Considerations does:

That inhumane Prince Harry the Eight, who had rejected the Power of the Roman See, but obstinately retained the Doctrine of their Church, put to death both Protestants and Papists without Distinction, for holding those Opinions which were looked on as fundamental to the Principles of each (p. 8).

Political Principle of The Kirk in Power (Dublin, 1713); William Tisdall, The Nature and Tendency of Popular Phrases in General (Dublin, [1715?]).

37 The Advantages Propos'd by Repealing the Sacramental Test (Dublin, 1732), p. 4. Tisdall mentions that nonconformists are 'oblig'd to attempt the subversion of the Religion Establish'd', but places no particular emphasis on this theme: William Tisdall, The Case of the Sacramental Test Stated and Argu'd (Dublin, 1715), p. 9.

${ }^{38}$ Claude Rawson, 'The Character of Swift's Satire: Reflections on Swift, Johnson, and Human Restlessness', in Claude Rawson, Order from Confusion Sprung: Studies in Eighteenth-Century Literature from Swift to Cowper (London, 1985), pp. 3-67; quotation at p. 11. 
This passage does however express with admirable concision the views about Henry VIII that Swift set down elsewhere:

... he was an entire defender of all the Popish doctrines, even those which were the most absurd. And, while he put people to death for denying him to be head of the church, he burned every offender against the doctrines of the Roman Faith... ${ }^{39}$

In his marginal notes to Herbert's Life and Raigne of Henry (1649), Swift describes the royal subject as a 'profligate Dog of a King', a 'Bloody inhuman Hell-hound of a King', and a 'Viper Devil Monster' among other exuberant epithets. ${ }^{40}$

There are many more verbal parallels set out in the appendix below. One of the most important concerns the complaints of Ulster Presbyterians during the invasion scare of 1708 that the test act disabled them from accepting commissions in the militia. In this connection the Person of Quality cites Swift's old friend Tisdall, the vicar of Belfast. Tisdall's longest pamphlet, The Conduct of the Dissenters (1712) devotes ten pages to the militia array of 1708. He runs through the various addresses published by the Dissenters at that time, Daniel Defoe's Irish pamphlet, The Paralel (1705) - which he saw as the inspiration for Presbyterian insolence, and two testimonials provided by Brett Spencer of Lisburn and Westenra Waring of Waringstown giving details of Presbyterian resistance to the imposition of the oath of allegiance during the militia array - the latter case focusing on Clotworthy Upton and his tenants at Templepatrick. ${ }^{41}$ But Tisdall nowhere uses the phrase 'fight your own battles' that would recur in Swift's writings. In Some Considerations upon the Late Attempt the author complains that 'Some Years ago upon the Rumour of an Invasion from the Pretender, the Dissenters in all their printed Papers [declared that...] They would not fight other Folks Battels' (p. 10). Now compare this accusation with three of Swift's tracts on the test:

\begin{tabular}{|c|c|c|}
\hline $\begin{array}{l}\text { Letter concerning the Sacramental } \\
\text { Test (1709), pp. 9-10. }\end{array}$ & Quaries wrote by Dr. J. Swift (1732) & Plea of Merit (1733), p. 14 \\
\hline $\begin{array}{l}\text {... they tell us of their Merits in the } \\
\text { last War in Ireland, and how } \\
\text { cheerfully they Engaged for the } \\
\text { Safety of the Nation; that had they } \\
\text { thought they had been Fighting only } \\
\text { other People's Quarrels, perhaps it } \\
\text { might have cool'd their Zeal, and that } \\
\text { for the future, they shall sit down } \\
\text { quietly, and let us do our Work our } \\
\text { selves... }\end{array}$ & $\begin{array}{l}\text { WHEN an artificial Report was raised here many Years ago, } \\
\text { of an intended Invasion by the Pretender, (which blew over } \\
\text { after it had done its Office) the Dissenters argued in their Talk, } \\
\text { and in their Pamphlets, after this Manner, applying themselves } \\
\text { to those of the Church. Gentlemen, if the Pretender had } \\
\text { landed, as the Law now standeth, we durst not assist you; and } \\
\text { therefore, unless you take off the Test, whenever you shall } \\
\text { happen to be invaded in earnest, if we are desired to take up } \\
\text { Arms in your Defence, our Answer shall be, Pray, Gentlemen } \\
\text { fight your own Battles... }\end{array}$ & $\begin{array}{l}\ldots \text { the Presbyterians in their } \\
\text { Pamphlets argued in a } \\
\text { menacing Manner, that if the } \\
\text { Pretender should invade those } \\
\text { Parts of the Kingdom where } \\
\text { the Numbers and Estates of the } \\
\text { Dissenters chiefly lay; they } \\
\text { would sit still, and let us fight } \\
\text { our own Battles... }\end{array}$ \\
\hline
\end{tabular}

39 Quoted in Michael Deporte, 'Avenging Naboth: Swift and Monarchy', Philological Quarterly, vol. 69, no. 4 (1990), pp. 23-24.

40 Ashley Marshall, Swift and History: Politics and the English Past (Cambridge, 2015), p. 40.

41 [Tisdall], Conduct of the Dissenters, pp. 31-41; see also idem, Case of the Sacramental Test, pp. 30-35. 
(ii) Party

The second theme of Some Considerations upon the Late Attempt is quite idiosyncratic. The author begins by introducing himself as a Whig - or rather an upholder of the core principles properly attributed to Whigs. In 1719 Swift was indelibly associated with the Tory ministry led by Robert Harley between 1710 and 1714, now discredited and portrayed as Jacobite conspirators. At first it might seem unlikely that he should identify himself as a Whig, and as a loyal subject of George I; but (as shown in the appendix) this stance is entirely consistent with Swift's other writings on church affairs. Swift repeatedly described himself as a Whig in civil affairs but an ecclesiastical Tory. In a sharp exchange with William King at the end of 1716 he reminded the archbishop that he had always been 'a Whig in Politicks'. ${ }^{42}$ Elsewhere he described himself as holding to 'the old Whig principles, without the modern articles and refinements'. ${ }^{43}$ But as the Person of Quality explained, it was possible to be a Whig and yet reject the demands currently being made by 'our Dissenting Brethren' for 'an equal share of Civil Power' (p. 9).44

Having maintained in the first half of Some Considerations upon the Late Attempt that the Dissenters are not as loyal as their friends contend, the author now gently submits that the Tories are not as disaffected as their enemies have portrayed them. He observes that Dissenters can take up employments simply by receiving the Anglican sacrament once a year, whereas the Tories, although willing to swear the oaths of allegiance, are excluded 'as effectually as a Papist or a Jew' (p. 12). The purge of Tory office-holders following the Hanoverian accession had indeed been draconian. It extended from the top to the bottom of every branch of the Irish administration. Swift's friends Thomas Lindsay (later Primate) and Constantine Phipps were replaced as lords justices; the entire privy council was dissolved; there was a clean sweep of patentee officers at Dublin Castle; eight of the ten judges were removed; up to 50 revenue officers were dismissed along with four of the seven commissioners; the commander-in-chief of the army and eight of his regimental commanders were discharged. ${ }^{45}$ 'Every thing is as bad as possible', Swift had remarked to a friend in October 1714, 'and I think if the Pretender ever comes over, the present men in Power have traced him the Way'. ${ }^{46}$

The author next proceeds to the delicate problem of the 'Discontents' that arose following the Hanoverian accession. He briskly attributes Jacobitism to three causes: the 'unhappy and

\footnotetext{
42 Swift to King, 22 Dec. 1716, in David Woolley (ed.), The Correspondence of Jonathan Swift, D.D. (5 vols., Frankfurt am Main, 1999-2014), II, 204; hereafter cited as Corr. The best discussion of Swift's party allegiances is Ian Higgins, Swift's Politics: A Study in Disaffection (Cambridge, 1994). Also relevant to this discussion is this characteristically original article by Ashley Marshall: “fuimus Torys”: Swift and Regime Change, 1714-1718', Studies in Philology, vol. 112, no. 3 (Summer, 2015), 537-74.

43 Swift to Lady Elisabeth Germain, 8 Jan. 1733, Corr. III, 576.

44 As a general rule Swift identifies himself as a whig only when he is attacking whig governments.

45 Patrick McNally, 'The Hanoverian Accession and the Tory Party in Ireland', Parliamentary History, 14 (1995), 263-83.

46 Swift to Knightley Chetwode, 6 Oct. 1714, Corr. II, 85.
} 
mistaken Opinion of Danger to the Church'; the alleged 'Dispositions' of some of the ministers who then took power; and the 'universal Change of Persons and Measures' which immediately occurred (p. 13). The context here was of course the disastrous rebellion of 1715.47 In the immediate aftermath of the insurrection Swift felt that all those who did not support the Whigs were 'used like Jacobites and Dogs'. ${ }^{48}$ In the coming years the politically reliable clergymen selected to preach before the lord lieutenant or parliament on state anniversaries blamed the 1715 revolt on Harley's Tory administration and on the doctrine of indefeasible hereditary right propagated by high churchmen. ${ }^{49}$ It was the phony cry of the 'church in danger' that had seduced men into rebellion. A good example was the sermon preached by Archbishop Synge of Tuam, on 1 August 1719, the anniversary of the accession of George I. Next to Archbishop King, Synge was the most prominent opponent of the ministry in the Lords, both on the toleration bill and on the question of appellate jurisdiction. It must have been sickening for Swift to hear men such as Synge relate how Queen Anne's last ministry had plotted to 'set up the Exploded Right and Title of the Pretender', had sued for 'a most Inglorious Peace' with Britain's enemies, and had cynically revived 'the cry of the Danger of the Church'. ${ }^{50}$ As everyone knew, Swift had been their brilliant chief of propaganda.

Diplomatically, the Person of Quality chose to minimize the size of the Tory party in Ireland rather than defend it. Not only were the Tories 'daily decreasing' in number, but some had been 'convinced of their Errors, and have received suitable Marks of Favour'. By adopting a more conciliatory stance the regime would soon have the majority of 'that venerable Body' behind them, and the loyalty of the Tories, 'though founded upon Principle, will yet be stronger established by the Opinion of Safety and Security in their Privileges and Possessions'. Turning to the church more specifically, the author admitted that 'disaffected Clergy-men' existed but protested that the crimes of a few should not lead to the collective punishment of the clergy as a whole (pp. 20-21). By lightly interweaving his themes rather than by explicit statement, Some Considerations upon the Late Attempt associates the clergy with patriotic concerns. The Person of Quality denounced the English bishops who regarded their Irish brethren as 'a Race of inferior Mortals', as we have seen, but he also lamented the situation in which 'the Sons of Gentlemen who have the Misfortune to be Born on Irish Ground, if they try their Fortune in the Church, the Law, or the Revenue, must be content to dye in the Condition of a Country Curate, a Petty-fogger, or an Excise-man' (pp. 17, 19). Finally he mentioned the objections of 'several well-affected Clergy-men' to recent legislative proposals that would have facilitated

\footnotetext{
47 Swift was more forthright in the unpublished Account of the Court and Empire of Japan (1727-28), where he bluntly observes that George I, by shunning the moderate Tory leaders, 'occasioned a rebellion' (Davis, Prose Writings, V, 99-100).

48 Swift to Chetwode, 17 Dec. 1715, Corr. II, 150.

49 Theophilus Bolton, A Sermon Preach'd in Christ's-Church, Dublin, upon the Thirtieth of January, 1716/17. Before His Excellency Henry Earl of Galway (Dublin, 1717), pp. 4, 5, 8-9, 20-21; Edward Synge, The Happiness of a Nation, or People. In a Sermon Preached at Christ's-Church, Dublin, before the Government, and House of Lords, May 29th. 1716 (Dublin, 1716), p. 28.

50 Edward Synge, A Sermon Preach'd at St. Andrew's Dublin: before the Honourable House of Commons; On Saturday, August the 1st. 1719 (Dublin, 1719), pp. 22, 32-3.
} 
the alienation of bishops' lands (p. 20). ${ }^{51}$ In 1723 a second attempt was made to remove the restrictions on bishops' lands, provoking Swift's Some Arguments against Enlarging the Power of Bishops. It is worth noting that the printing of this pamphlet was arranged by the bookseller John Hyde - of whom more below - and that Swift was the only writer to appear on behalf of the church.

\section{(iii) The Definition of Slavery}

The definition of slavery recorded in Some Considerations on the Late Attempt was derived from William Molyneux's Case of Ireland, Stated (1698). 'I am loth to give their Condition an hard Name', Molyneux remarked of the people of Ireland, but I have no other Notion of Slavery, but being Bound by a Law to which I do not Consent.' 52 In 1698 the publication of Molyneux's treatise was initially viewed as counter-productive by Irish patriots, who rightly feared it would antagonize English MPs. Against the background of Annesley v. Sherlock, however, it was reprinted in Dublin and was becoming - as Patrick Kelly has commented - the 'authentic articulation of colonist aspirations'. Bishop Evans spoke of the book as being the source of inspiration for Irish Protestant resistance; by August he was fuming that it was held to be 'altogether unanswerable' by King and his supporters. ${ }^{53}$ Leaving aside Some Considerations upon the Late Attempt, however, the only writer to repeat the definition of slavery in print was Swift, in his fourth and fifth Drapier's Letters, where he ascribes the principle to 'the Famous Mr. Molineaux, an English Gentleman born here'. ${ }^{4}$ Kelly comments that this direct reference was 'unique'; it was certainly unprecedented. 55

\footnotetext{
${ }^{51} \mathrm{He}$ was referring to the misleadingly entitled bill 'For explaining and amending an act entitled an act for the preservation of the inheritance, right and profits belonging to the church and persons ecclesiastical', which went through the Commons in the summer of 1719 and was rejected by the Irish Privy Council. For a discussion of the 1723 conflict between churchmen and landlords see Louis A. Landa, Swift and the Church of Ireland (Oxford, 1954), pp. 97-111.
}

52 P. H. Kelly (ed.), William Molyneux's The Case of Ireland's Being Bound by Acts of Parliament in England, Stated (Dublin, 2018), p. 169.

53 Patrick Kelly, 'William Molyneux and the Spirit of Liberty in Eighteenth-Century Ireland', ECI, 3 (1988), 137; Evans to Wake, 9 Aug. 1719, Christ Church, Oxford, Wake MS XIII, 101.

${ }^{54}$ Davis, Drapier's Letters, p. 79. Early in 1698 Francis Brewster remarked that 'Slavery' exists where 'Men are governed by Laws they have no hand in making', but this was before the publication of Molyneux's Case. ' $\mathrm{F}$. B.', A Letter to a Member of the House of Commons on a Proposal for Regulating and Advancing the Woollen Manufactory (London, 1698), pp. 12; for the dating of this pamphlet see Kelly (ed.), William Molyneux's The Case of Ireland's Being Bound by Acts of Parliament in England, Stated, 'General Introduction', pp. 15-16. The Jacobite Charles Leslie mischievously observed that, by Molyneux's definition, Irish Catholics were slaves: [Charles Leslie], Considerations of Importance to Ireland, In a Letter to a Member of Parliament there; upon occasion of Mr. Molyneux's Late Book (n. pl., n. d., [1699]), p. 3.

${ }^{55}$ Kelly, 'William Molyneux and the Spirit of Liberty', p. 137. For the reception of Molyneux's treatise see also Isolde L. Victory, 'Colonial Nationalism in Ireland, I692-1725: From Common Law to Natural Right' (Trinity College, Dublin, Ph.D. thesis, 1984), esp. ch. 4; idem, 'The Making of the 1720 Declaratory Act', in Gerard O'Brien (ed.), Parliament, Politics and People: Essays on Eighteenth-Century Irish History (Dublin, 1989), pp. 
The only other reference to Molyneux's definition of slavery during the first half-century after its publication occurs in a pamphlet on Irish wool published by John Perceval, Earl of Egmont, in 1731; it was almost certainly a conscious echo of the Drapier's Letters. ${ }^{56}$ The closest thing I can find to another mention is Hercules Rowley's An Answer to a Book, Intitl'd, Reasons Offer'd for Erecting a Bank in Ireland (1721), the main pamphlet attacking the bank project of that year. One of the arguments was that a bank could become an instrument of arbitrary power because 'Ireland is a dependant Kingdom, and is bound by Laws not of it's [sic] own making'. ${ }^{57}$ It was widely known at the time that Rowley was not the real author of this work, and Craig Pett has made the strongest case yet for attributing the pamphlet to his friend Jonathan Swift. There is, I think, an oblique acknowledgement of the Dean's authorship in a letter written to Knightley Chetwode, in which he comments that the bank controversy has 'filled the Town with Pamphlets, and none writt so well as by $\mathrm{M}^{\mathrm{r}}$. Rowley though he was not thought to have many Talents for an Author' ${ }^{58}$

Although the phrase was widely used in conversation and correspondence, particularly by Archbishop King, the use of Molyneux's 'Notion' in print was surprisingly rare. ${ }^{59}$ Irish commentators on the question of appellate jurisdiction were reluctant to challenge the legislative supremacy of Westminster in public, let alone describe it as slavery. Even the radical whigs Robert Molesworth and John Toland shied away from the topic, since 'the point of binding Ireland by British Laws, was too nice a matter to be enter'd into. ${ }^{60}$ The rhetoric of enslavement was habitually used in declarations of loyalty (where it was associated with popery and Jacobitism) but not in Irish criticisms of English aggression. Fifty pamphlets were written against Wood's halfpence, in addition to the Drapier's Letters, but only one of these contains

9-29; Jacqueline Hill, 'Ireland without Union: Molyneux and his Legacy', in John Robertson (ed.), A Union for Empire: Political Thought and the British Union of 1707 (Cambridge, 1995), pp. 271-96.

56 John Perceval, Some Remarks on the Conduct of the Parliament of England, as far as it Relates to the Woollen Manufacture (London, 1731), pp. 29-30. Answering the charge that he had 'maintain'd the Doctrine of Mr. Molineux', Perceval replied in a long ironic passage concluding that 'I have not so much as mention' $d$ the common Definition of Slavery, which is, to be bound by Laws we do not consent to.'

${ }^{57}$ Hercules Rowley, An Answer to a Book, Intitl'd, Reasons Offer'd for Erecting a Bank in Ireland (Dublin, 1721), p. 49; this repeats a slightly different formulation on pp. 4-5 and 47.

58 Swift to Chetwode, 5 Dec. 1721, Corr., II, 404, my italics; Craig Francis Pett " II am no inconsiderable ShopKeeper in this Town". Swift and his Dublin Printers of the 1720's: Edward Waters, John Harding and Sarah Harding' (Ph.D. thesis, Monash University, 2015), pp. 172-72.

59 King wrote to Thomas Lindsay, then Tory bishop of Killaloe: 'if I can be taxed \& bound by laws to which I am no party; I shall reckon myself as much a Slave, as one of the grand seigniour's mutes': 13 May 1698, TCD MS 750/1, p. 230. See also Cox to Nottingham, 13 Feb. 1704, Cal. S. P. (Dom) 1703-4, II, 53; Midleton to [Joseph Addison], 9 Sep 1717, SHC, Midleton Papers, MS 1248/4/68-69B; D. W. Hayton, 'The Stanhope/Sunderland Ministry and the Repudiation of Irish Parliamentary Independence', EHR, vol. 113, no. 452 (June, 1998), p. 618

60 Several Speeches in the House of Commons in England, For and Against the Bill for the Better Securing the Dependency of the Kingdom of Ireland, on the Crown of Gr. Britain (Dublin, 1720), p. 11. [John Toland], Reasons most Humbly Offer'd to the Hon[oura]ble House of Commons, why ... An Act for the Better Securing the Dependency of the Kingdom of Ireland upon the Crown of Great-Britain, Shou'd not Pass into a Law (London, 1720), p. 13. 
an indirect reference to the enslavement of Ireland. ${ }^{61}$ Most patriot writers preferred to concentrate on the economic aspects of the controversy. Defenders of the sacramental test had even more reason to steer clear of constitutional disputes. It was unwise for Irish churchmen to launch a broader attack on English misgovernment, thus running the risk of alienating English co-religionists. The exception was Jonathan Swift.

\section{Other Evidence}

The case for attributing the 1719 pamphlet to Swift is based mostly on intertextual evidence (see Appendix II). Swift recycled ideas across his polemical career. ${ }^{62}$ This is true of his definition of slavery, but equally true of his views on the repeal of the test, where points first made in 1709 were repeated more than a decade later in Some Considerations upon the Late Attempt, and then dusted off again in 1732-33. Over a quarter-century his campaigning against the Dissenters showed remarkable continuity. In addition to the repetition of arguments and phrases, the 1719 pamphlet features certain verbal tics such as 'I could heartily wish' (p. 10) one of Swift's favourite formulae for taking up a new point. ${ }^{63}$ But other evidence, drawn from the printing of the pamphlet, and from Swift's correspondence, also supports the case made here.

\section{(i) The Printing of Some Considerations upon the Late Attempt}

Swift's usual practice was to publish anonymously. He took great care to conceal his identity. In George Faulkner's Works of J.S, D.D., D.S.P.D. (1734-69) the editor remarks that all but

61 A Letter to the Lord C-----t, in Answer to Some Arguments Lately Advanced in Favour of Mr. Wood's Copper Money (Dublin, 1724) deplored the Romans (and by implication the English), who were happy to see 'the whole World, except themselves, Slaves' (p. 3). The author of A Letter to M. B. Drapier, Author of a Letter to the Ld Molesworth, \&c. (Dublin, 1725) hints at the definition of slavery when he affirms Molyneux's view that 'We are in a miserable Condition indeed, if we may not be allow'd to complain, when we think we are hurt' (p. 5). But this pamphlet was published after the explicit references to Molyneux in the fourth and fifth Drapier's Letters. The other prose tracts and broadsides on Wood's halfpence are ESTC T167002, N49129, N38451, N48985, T206015, T177210, T206718, N60659, T71494, T194730, T209697, T87748, T210813, T169027, T155344, T69228 (also T155363), N60847, T71493, T167835, T87128, N478214, T34948, N2560, N60660, T200562, T56979, T175295, T179299 (also T217018), T71492, N2734, T18215, T1988, T160450, T47299, T87754, T87764, T71471, T87763, T175295, T214755 (also T203071, N68954), N33937, T214539, T195442, N67172, N66185. There are three further items not listed by the ESTC: Wood's Confession to the Mobb of the City of Dublin (Dublin, 1724), V\&A, Forster 48.G.6/1 (no. 14); 'N. N.', A Third Letter from ------ to the -----([Dublin, 1724]) and 'N. N.', Fourth Letter from a Friend to the Right Honourable -------- ([Dublin, 1724]) both in the British Library. They are reproduced in Sabine Baltes, Jonathan Swift's Allies: The Wood's Halfpence Controversy in Ireland, 1724/25 (Frankfurt, 2004).

62 This tendency is very evident in Hayton and Rounce, A Modest Proposal and Other Works. The editors' comment that Swift was often 're-treading old ground' applies also to his writings on the church (p. xxiii).

63 There are six examples in Hayton and Rounce, A Modest Proposal and other Works, pp. 125, 126, 205,251 (twice), 329; see also A Letter to a Young Gentleman, lately enter'd into Holy Orders. By a Person of Quality (London, 1721), p. 3. 
two of the 162 items included had appeared without the author's name. ${ }^{64}$ The 1709 Letter concerning the Sacramental Test, The Advantages Propos'd by Repealing the Sacramental Test (1732) and The Presbyterians Plea of Merit (1733) were all anonymous. When Faulkner brought out a Dublin edition of Bishop Gibson's The Dispute Adjusted (1733), appending two of Swift's pieces to it, he ventured to add the line 'By the Reverend Dr. J. S. D.S.P.D.' to the title page. The editions of the Letter concerning the Sacramental Test produced by Faulkner in 1732, 1733, and 1734 also identified Swift by his initials or by indirect statements in the preface: these innovations were intended as publicity for the forthcoming Works. ${ }^{65}$ It was in keeping with Swift's normal practice, then, that the title page of Some Considerations on the Late Attempt described the author only as 'A Person of Quality' - a nom de plume Swift had used for the Project for the Advancement of Religion (1709) and that was used again when his Letter from a Lay-Patron to a Gentleman was republished in London in 1720 just twelve weeks after Some Considerations upon the Late Attempt appeared.

64 The Works of J.S, D.D, D.S.P.D. in Four Volumes (Dublin, 1735), vol. IV, A2r 'The Publisher's Preface'.

65 The other exception was the single sheet folio, Quaries wrote by Dr. J. Swift (1732) which appeared without an imprint. 


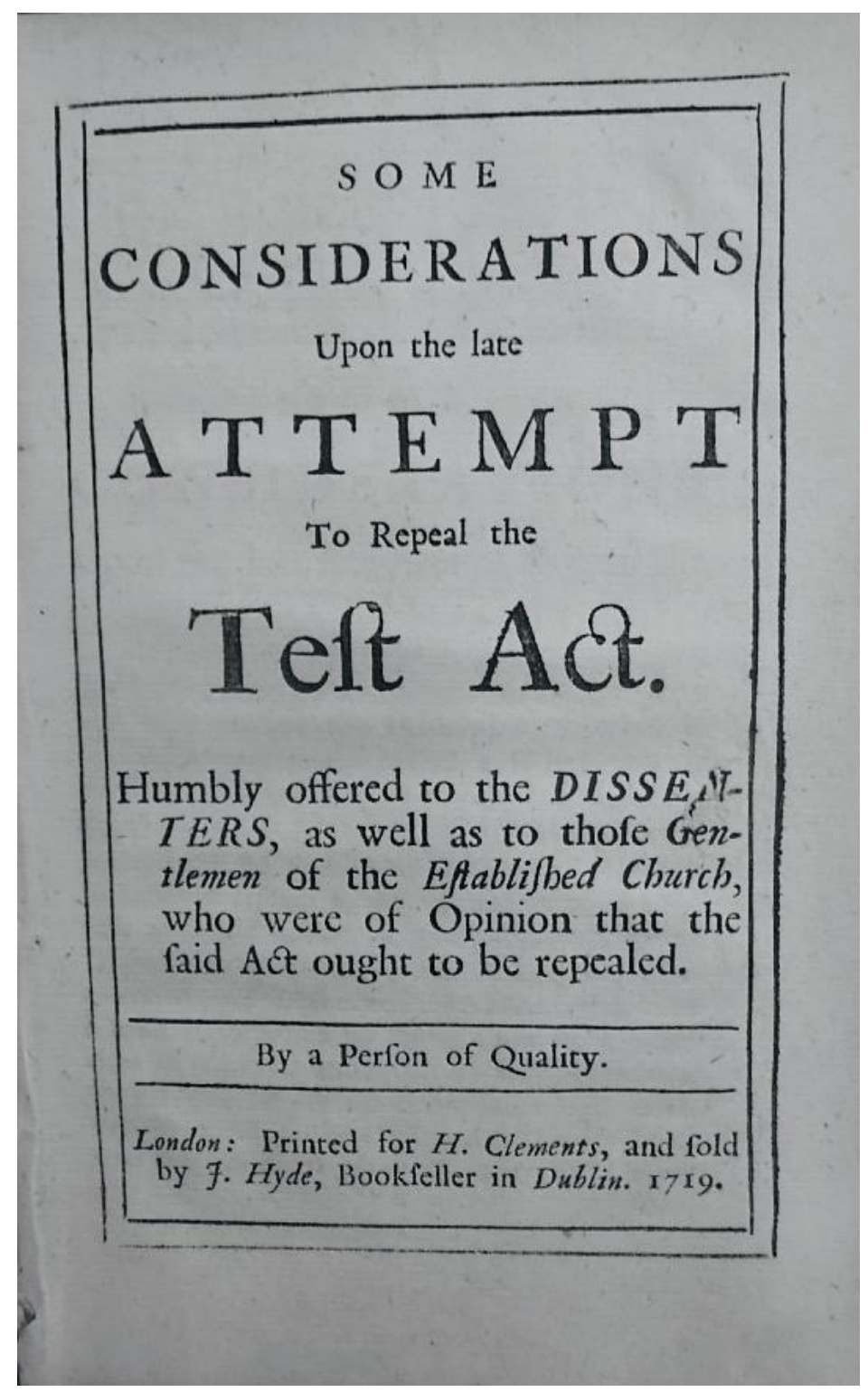

Although the imprint states that the Some Considerations upon the Late Attempt was printed in London by Henry Clements, a well-known printer and bookseller located at St. Paul's Cathedral, the distribution of surviving copies is typical of a pamphlet produced in Dublin. ${ }^{66}$ There are currently seven copies in Irish libraries. Only three can be found in Britain, meanwhile, and of these the Bradshaw Collection in Cambridge is a specifically Irish collection, and the copy in Christ Church, Oxford was the one forwarded to William Wake by Bishop of Nicolson of Derry. That leaves only the British Library. It would be extraordinary for a London-printed work to be represented by a single English copy. In his recent article 'False and Incomplete Imprints in Swift's Dublin, 1710-1735', James May has argued convincingly that Some Considerations upon the Late Attempt was in fact printed by Aaron Rhames in Dublin, whose ornament it contains (a tailpiece featuring a prancing lion, front left

\footnotetext{
${ }^{66}$ For details see ESTC. In the preparation of this article I have consulted the following: British Library, 4135. b. 29; Christ Church, Oxford, Z 33, no. 14; no. 5; National Library of Ireland, P284 (2); Royal Irish Academy, HP 47/5 and HP 48/3; Trinity College Dublin OLS 188 p 91, no. 5.
} 
foot raised, facing right). Like a number of other printers, Rhames may have disguised his connection with the pamphlet for fear of alienating his Dissenter customers. ${ }^{67}$ The undertaker for the publication was the Dublin Tory bookseller John Hyde, a figure well-known to Swift scholars. Hyde was Master of the Guild of St Luke's in 1718 and was described as 'the most Eminent and noted Bookseller in this City', on his death in $1728 .{ }^{68}$ In April 1719 Swift had chosen Hyde to organise the distribution of Matthew Prior's poems to Irish subscribers. ${ }^{69} \mathrm{He}$ would turn to Hyde again for Some Arguments against Enlarging the Power of Bishops in 1723 and for the Dublin edition of Gulliver's Travels in $1726 .^{70}$

It is an inconvenient fact that Some Considerations upon the Late Attempt is missing from Faulkner's 1735 Works of J. S, D. D, D. S. P. D. In contrast, the earlier Letter concerning the Sacramental Test had been reprinted by Faulkner three times in 1732, 1733 and 1734, before being placed at the beginning of volume IV of the Works. The reason surely has to do with Swift's well-known carelessness in preserving copies of his own publications and in leaving the job of supplying copy-texts for Faulkner to his circle friends. Swift 'did not keep careful track of his own writings', as Stephen Karian has commented. ${ }^{71}$ Charles Ford collected a run of the Examiner, and eighteen other pamphlets written by Swift during Queen Anne's reign, precisely because he knew the author was 'too negligent in keeping copies'. ${ }^{72}$ The survival of the Letter concerning the Sacramental Test was guaranteed because it had already been reprinted both in the 1711 Miscellanies in Prose and Verse and the later Pope-Swift Miscellanies (1727). When Faulkner produced his editions in 1732-34 he took his copy from the latter. ${ }^{73}$ It is possible that Some Considerations upon the Late Attempt was simply forgotten because the specificity of its message - that Tories were not so disaffected after all - became redundant once the Whig schism had ended, the Declaratory Act had passed, and political debate moved on to the bank project and Wood's halfpence. When Faulkner reprinted the

67 James E. May, 'False and Incomplete Imprints in Swift's Dublin, 1710-35', in Janika Bischof, Kirsten Juhas and Hermann J. Real (eds.), Reading Swift: Papers from The Seventh Münster Symposium on Jonathan Swift (Leiden, 2009), p. 60.

68 Paddy Bullard and James McLaverty, 'Introduction', in Jonathan Swift and the Eighteenth-Century Book (Cambridge, 2013), p. 14.

69 Swift to Prior, 28 April 1719, Corr. II, 297.

70 The edition contains important authorial revisions: David Woolley, 'Swift's Copy of Gulliver's Travels: The Armagh Gulliver, Hyde's Edition, and Swift's Earliest Corrections', in Clive T. Probyn (ed.), The Art of Jonathan Swift (London, 1978), pp. 131-78.

71 See Stephen Karian, Jonathan Swift in Print and Manuscript (Cambridge, 2010), pp. 31-33, quotation on 32; see also Ashley Marshall, 'The "1735" Faulkner Edition of Swift's Works', The Library, 7"th ser., vol. 14, no. 2 (June 2013), pp. 154-87, esp. 157, 159; James McLaverty, 'George Faulkner and Swift's Collected Works', in Bullard and McLaverty, Jonathan Swift and the Eighteenth-Century Book, p. 163.

72 Ford to Swift, 6 Nov. 1733, Corr. III, 698.

73 See [Swift], A Letter from a Member of the House of Commons in Ireland, to a Member of the House of Commons in England. Concerning the Sacramental Test ([Dublin], 1734), A2r, 'The Publisher's Advertisement to the Reader'. 
earlier Letter concerning the Sacramental Test he explained that 'the Author's Way of Reasoning' was even more relevant than when the pamphlet first appeared. ${ }^{74}$ This could not be said of the apology for Tory churchmen offered by the Person of Quality in $1719 .{ }^{75}$

\section{(ii) Contemporary Correspondence}

It is remarkable that so few of Swift's letters from 1719 have survived - only twelve in total and none at all for the summer months. ${ }^{76}$ Between June and September the Dean was rambling on horseback, as was his custom, and visiting George Mathew of Thomastown Castle in Tipperary. ${ }^{77} \mathrm{He}$ was therefore unlikely to have been in the capital when the Duke of Bolton delivered his speech from the throne and the Lords and Commons drew up their responses, carefully expressing their willingness to promote unity among all loyal subjects insofar as that was 'consistent with the Peace and Security of our present happy Constitution in Church and State'. ${ }^{78}$ A further declaration from the King followed on 10 August, pointedly reiterating his desire to strengthen the Protestant interest by improving the position of those "who, by the Legal Incapacities they now lie under are disabled from Contributing to its Support'. ${ }^{79}$ Some Considerations upon the Test refers to the latter address as well as Bolton's speech, so it was written - or at least completed - after mid-August. The various addresses prompted by the speech from the throne were published as free-standing items and could easily have reached Swift in the country.

The five years between 1714 and 1719 form the period when Swift felt a sense of exile most keenly. For several years he was regarded as a subversive by the authorities and was under surveillance; he was aware that his post was often opened. As late as 1719 Swift kept up the pretence that he knew nothing at all of political affairs, while simultaneously taking a keen interest in polemical pamphlets sent to him from England. ${ }^{80}$ At the end of the year he described

74 Works of J.S, D.D., D.S.P.D., p. ii, 'The Publisher's Advertisement to the Reader'.

75 Some Considerations upon the Late Attempt was consistent with Swift's letters to Archbishop King (see below), but his later comments on party took the form of satirical attacks on Whig paranoia, such as A Vindication of His Ex[cellenc]y the Lord C[arteret], from the Charge of Favouring None but Toryes, High-Churchmen and Jacobites (Dublin, 1730) and An Examination of Certain Abuses, Corruptions, and Enormities, in the City of Dublin (Dublin, 1732). Both are reprinted in Hayton and Rounce, A Modest Proposal and other Works.

76 This is nevertheless an improvement on the period between 19 August 1717 and 20 August 1718: just one letter from an entire year.

77 Swift to Esther Vanhomrigh, 12 May 1719, Corr., II, 305, n. 2. Mathew’s nephew was a pupil of Sheridan. See further R. W. Jackson, 'Dean Swift's Tour of Munster', Dublin Magazine, xviii (1943), pp. 33-39.

78 Journals of the House of Commons of the Kingdom of Ireland (19 vols., Dublin, 1796), III, 186; JHLI, II, 606 (the wording of the Lords differed slightly).

79 To the King's Most Excellent Majesty, The Humble Address of the Lords Spiritual and Temporal in Parliament Assembled (Dublin, 1719). The king's reply is printed on the verso of this broadside, mispaginated ' 6 '.

80 Swift to Ford, 6 Jan. 1719, Corr., II, 287-89. 
his own circle as consisting of a 'dozen Persons' only. ${ }^{81}$ This is not to say that Swift's correspondence is irrelevant to the arguments presented above. It is certainly not in conflict with any of them. The first extant letter from 1719 discusses the bill for the repeal of the Occasional Conformity and Schism Acts going through Westminster in December. ${ }^{82}$ This was Stanhope and Sunderland's attempt to relieve the English Dissenters. In April Swift records meeting the bookseller John Hyde to discuss the distribution of Matthew Prior's Poems on Several Occasions (1719). ${ }^{83}$ Two months earlier he informed Charles Ford that he had sent for 'one Hide' who had been 'recommended to me as an honest man'. ${ }^{84}$ On 22 May Swift wrote a letter to Bishop Evans, his last before his summer travels. Evans had refused to accept Swift's appointment of a proxy to represent him at the annual episcopal visitation at Trim. The Dean had absented himself following the 'injurious treatment' he had experienced the previous year. Their quarrel culminated in Swift's sharp retort: 'please to remember in the midst of your resentments that you are to speak to a clergyman, and not to a footman'. ${ }^{85}$ Five months later Evans was one of the foreign bishops denounced by the Person of Quality for treating Irish churchmen as 'a Race of inferior Mortals'.

\section{(iii) Alternative Candidates}

When Bishop Nicolson forwarded a copy of Some Considerations upon the Late Attempt to William Wake, he remarked that "'Tis not yet agreed, whether a great neighbouring prelate (or his Dean) be $\mathrm{y}^{\mathrm{e}}$ true Author of the Work'. ${ }^{86}$ The Duke of Bolton suspected that there were actually two authors of this 'malitious book' and claimed he knew who they were: ' $y$ ' first part I take to be writ by one person, And from p. 15, I beleive [sic] or at least conjecture to be writ by another, who very often talkes and Hold's these tenent's [sic] very freely'. ${ }^{87}$ Bolton was almost certainly thinking of the Archbishop of Dublin, the greatest ecclesiastical statesman of the era. Could he have been right? King was certainly a veteran author and controversialist. His Discourse Concerning the Inventions of Men in the Worship of God (1694), written while he was dean of Derry with the aim of convincing Ulster Presbyterians of their errors on liturgical and ecclesiological points, was reprinted many times, in London, Edinburgh and Boston, as well as Dublin. His State of the Protestants of Ireland under the Late King James's Government (1691) was the standard apologia for the conduct of Irish Protestants during the

\footnotetext{
81 Swift to Ford, 8 Dec. 1719, Corr., II, 310.

82 Swift to Ford, 6 Jan. 1719, Corr., II, 288.

83 Swift to Prior, 28 April 1719, Corr., II, 297; see also Swift to Ford, 3 May 1719, Corr., II, 301.

${ }^{84}$ Swift to Ford, 16 Feb. 1719, Corr., II, 292.

85 Swift to Evans, 22 May 1719, Corr., II, 306.

86 Nicolson to Wake, 17 Oct. 1719, Christ Church, Oxford, Wake MS XIII, 117.

${ }^{87}$ Bolton to [London], 15 Oct. 1719, TNA SP 63/378, f. 83v.
} 
Williamite wars, and had been reprinted in 1692 and 1713. ${ }^{88}$ In 1719, moreover, King was the lynchpin of resistance to the government's toleration bill and simultaneously to the encroachments of Westminster on the appellate jurisdiction. King was the recognized head of a rainbow coalition of Irish peers: his closest ally was Archbishop Synge of Tuam, but his patriot bloc ranged from the anti-clerical 'commonwealthsman' Viscount Molesworth to the ultra-Tory Thomas Lindsay, archbishop of Armagh. During the first half of October King was the driving force in the Lords select committee which drew up the Humble Representation, defending Ireland's judicial autonomy. On 17 October it was finally endorsed, with eight Lords dissenting. The English-born bishops repeatedly identified King as the principal upholder of the 'Doctrine of Independency' 89

The trouble is that, with the exception of The State of the Protestants, written almost three decades earlier, King's writings were philosophical, theological and pastoral rather than political. After 1704, the year the sacramental test came into effect, he published six sermons, three works concerned with ecclesiastical administration, and an article in Philosophical Transactions (1708) entitled 'An Account of the Manner of Manuring Lands by Sea-Shells, as Practised in the Counties of Londonderry and Donegall in Ireland'. King published nothing at all after 1719.

It is true that King's papers include two manuscript pamphlets which were never put into print, but this fact strengthens rather than weakens my case. In 1698 he sent to Robert Southwell in London a detailed response to A Letter from a Gentleman in the Country, to Member of the House of Commons, which had appeared in December 1697. Almost certainly written by John Toland, this short inflammatory tract called for the subordination of Irish trade to English priorities and the abolition of the Dublin parliament. King's rejoinder claimed for Ireland's Protestant community 'the Liberty of English Men, which I think Consists in being Governed by Laws to which they have given their Consent Either in person or by their representatives' .90 If this letter was indeed intended for publication, however, King clearly changed his mind. The second manuscript is entitled 'Some Observations on the Taxes pay'd by Ireland to support the Government'. It was drafted in 1716, expanded in 1721, and circulated widely among the archbishop's Dublin circle. Two versions of this treatise have been preserved in Trinity College Dublin. It was apparently read by Molesworth, Samuel Molyneux, Thomas Prior (author of the well-known List of Absentees of Ireland) and almost certainly by Swift himself. 91

\footnotetext{
${ }^{88}$ For the latter see S. J. Connolly, "The Glorious Revolution in Irish Protestant Political Thinking," in S. J. Connolly (ed.), Political Ideas in Eighteenth-Century Ireland (Dublin, 2000), pp. 27-63.

${ }^{89}$ Nicolson to Wake, 6 Oct 1719, Christ Church, Oxford, Wake MS XIII, 114.

90 Patrick Kelly, 'A Pamphlet Attributed to John Toland and an Unpublished Reply by Archbishop William King', Topoi, vol. 4, no. 1 (1985), 81-90, quotation at 88. The original is in the British Library, MS Egerton 917, ff. 15154.

91 O. W. Ferguson, Jonathan Swift and Ireland (Urbana, IL, 1962), p. 187; Ian McBride, 'The Politics of A Modest Proposal: Swift and the Irish Crisis of the Late 1720s’, Past \& Present, 244: 1 (Aug. 2019), p. 109.
} 
The exceptional scale of the archival record relating to William King, which forms the basis of a meticulous biography by Philip O'Regan, makes it very unlikely that the archbishop was the author of Some Considerations upon the Late Attempt. ${ }^{92}$ There is no reference to the unpublished pamphlet in his letters. Nor is there anything in King's private correspondence to suggest that he would have looked kindly on the hints made by the Person of Quality about the rehabilitation of Irish Tories. The disaffection of Tory clergymen presented repeated difficulties for King, who was irritated by their sullen hostility to the House of Hanover and their open criticism of the new king's Lutheranism. ${ }^{93}$ Neither his Irish correspondence nor his letters from England to Swift express any sympathy for clerical Toryism. During the Lords debates, in any case, the archbishop concentrated on the absence of legal protection for the doctrine of the Trinity, as we have already seen. In the final struggle over the toleration bill King took his stand on the constitutional position of the national church, established by 'the original contract between $\mathrm{y}^{\mathrm{e}}$ people of Ireland \& Henry the $2^{\mathrm{d}}$ on the submission of this Kingdom'. It had been the government's practice ever since the reign of Elizabeth to maintain an 'exact conformity' between the churches of England and Ireland. But the toleration bill would make it impossible for the king to fulfil the obligations made in his coronation oath to maintain 'the doctrine, worship, discipline and government' of the church both in England and Ireland. ${ }^{94}$ The subtle sedition implicit in this claim was just as subversive as the anti-Lutheran sermons preached by unreconstructed Tories.

A second, even less promising candidate for the Person of Quality is Edward Synge II, archbishop of Tuam (1659-1741). The problem of party sympathy applies equally to Synge, however, who was a firm Whig. The direct anti-Toryism of his sermons in 1716 and 1719 is hard to reconcile with the stance adopted in Some Considerations upon the Late Attempt. Synge was a fervent patriot who conceded that Ireland 'an annex'd Kingdom', but believed that in its internal affairs it possessed 'all the Courts, powers and jurisdictions which belong to the Kingdom of England'. ${ }^{95}$ But his focus was the appellate jurisdiction of the Irish Lords, rather than the question of legislative independence, and his public and private writings are free from the aggression that distinguished Swift. He reminded Archbishop Wake that where English interests were concerned, or were 'thought to be so', and the Westminster Parliament had taken upon itself to legislate, 'we have alwaies Submitted' .96

Synge's pronouncements on the status of Dissenters were also quite different in content and tone from the polemical writings of Swift. He was a learned commentator on theological and

\footnotetext{
92 Philip O'Regan, Archbishop William King (1650-1729) and the Constitution in Church and State (Dublin, 2000).

${ }^{93}$ King believed that the clergy's conduct towards the King had led to the repeal of the occasional conformity and schism acts: King to [Edward Smith, bishop of Down and Connor], 22 Jan. 1719, TCD MS 750/5/120-2.

${ }^{94}$ King to Wake, 1 Dec. 1719, Christ Church, Oxford, Wake MSS XIII, 132.

${ }^{95}$ Synge to Wake, 17 Dec. I719, Christ Church, Oxford, Wake MSS, XIII, 136.

96 Ibid.
} 
political questions. The sermons he preached on state occasions were typically systematic disquisitions on the origins and limits of authority within both church and state, carefully differentiating the mainstream Anglican position from the rival schemes of papists, Presbyterians, Hobbists, non-jurors and the followers of Benjamin Hoadly, Bishop of Bangor. ${ }^{97}$ Synge's sophisticated treatment of toleration emphasised the centrality of 'inward persuasion' in religious affiliation, in terms borrowed from John Locke. He wrote in a latitudinarian vein, stressing the importance of charity and compassion among Protestants. In a sermon preached to the House of Commons while MPs were still discussing the toleration bill, Synge urged that Dissenters should not be harshly treated, provided they were 'honest peaceable Men':

And if their Consciences will not allow them to qualify themselves, according to the Laws, for Places and Employments, they ought to sit down contented with a full and free Liberty of going their own Way to Heaven, without any Molestation in their Persons or private Fortune, and not to create a Ferment and Disturbance among the People, by strugling [sic] for a greater Share of Power than what is necessary for their Safety here, of Salvation hereafter. ${ }^{98}$

The question of access to 'Places of Trust and Profit' was a different matter from freedom of worship. The former were not natural or inalienable rights but 'favours', and the rules of exclusion varied according to the positive law of individual states. ${ }^{99}$ In any case, as we have already seen, Synge's overriding preoccupation in October 1719 was not with the Presbyterians but with exotic fringe groups, such as the Muggletonians and Antinomians, who would now have 'full and free liberty to hold their Publick meetings, and there openly teach whatever heresys they please'. ${ }^{100}$

Nor is the pamphlet likely to be the work of William Tisdall, to whom the anonymous author of 1719 refers. Tisdall was certainly a Tory. But he did not use the 'slavery' motif; he tended to concentrate more on the 'two-kingdoms' ecclesiology of the kirk; and he doesn't seem to have written against the Presbyterians after 1715. Some Considerations upon the Late Attempt actually cites 'Doctor Tisdel' (p. 12), just as Swift would do in the Presbyterians Plea of Merit, spelling the name in the same way. The vicar of Belfast, in contrast, had signed his own name to three recent pamphlets and he consistently spelled it 'Tisdall'. His style could never be

\footnotetext{
97 See, for example, Edward Synge, The Authority of the Church in Matters of Religion (London, 1718); idem, A Sermon against Persecution on Account of Religion, Preached before His Grace Charles Duke of Grafton, Lord Lieutenant: and the Rt. Honble. the House of Lords of Ireland; in Christ's-Church, Dublin: on Monday, October, the 23d. 1721 (Dublin, 1721). On the same day the Commons were treated to another fine example by Theophilus Bolton, then chancellor of St Patrick's and chaplain to the Lord Lieutenant: A Sermon Preach'd in St. Andrew's, Dublin: before the Honourable House of Commons, on Monday, October 23. 1721 (Dublin, 1721).
}

98 Synge, Happiness of a Nation, p. 30.

99 Synge, Sermon against Persecution, pp. 7-8; see also his Authority of the Church in Matters of Religion, esp. pp. 36-7. The same point was made in the controversial sermon published by Synge's son, also Edward, several years later: The Case of Toleration Consider'd with respect Both to Religion and Civil Government (Dublin 1725), p. 30 .

100 Synge to Wake, 19 Nov. 1719, Christ Church, Oxford, Wake MSS XIII, 128/1. 
mistaken for Swift's. His writings show nothing of the immediacy or the conversational feel of Swift's pamphlets - or of Some Considerations upon the Late Attempt. ${ }^{101}$ It is not difficult to see why Swift advised that it would be 'a terrible mistake' for Tisdall to concentrate on 'writing for the public' as opposed to preaching. ${ }^{102}$ The latter's tracts are dense and plodding. They are crammed with local detail regarding altercations between country magistrates and particular Presbyterian ministers, and examples of Presbyterian insubordination in the towns and villages of Country Antrim. There are copious footnotes and sidenotes, denouncing the seventeenth-century works of English Puritans and Scots Covenanters as well as Ulster Presbyterians - and they reproduce passages of prominent Dissenting preachers such as Joseph Boyse of Dublin and John McBride of Belfast. Tisdall was obsessed with the latter in particular. All five of his anti-Presbyterian pamphlets castigate McBride, usually at some length; the Antrim gentleman and MP Clotworthy Upton also features prominently. By contrast, Some Considerations upon the Test Act is a metropolitan piece. It was carefully timed to influence a specific parliamentary debate, something we know Swift liked to do. ${ }^{103}$ It referred directly to a speech from the throne - something Swift would do in his Proposal for the Universal Use of Irish Manufacturers (1720) and in A Letter from a Lady in Town to her Friend in the Country, Concerning the Bank (1721).

Anyone who contrasts Tisdall's work with Some Considerations upon the Late Attempt will see that the style of the latter is refreshingly direct. The tone is one of sustained moderation and easy authority, momentarily giving way to a sensational denunciation of English interlopers just as, in Swift's Irish writings more generally, the author's indignation occasionally cuts through the placid surfaces constructed by his fictional personae. There are autobiographical hints: the author twice mentions that he has been in London, as Swift would do a few months later in the anonymous Proposal for the Universal Use of Irish Manufacture. ${ }^{104}$

One final candidate worth pondering is the schoolmaster, classicist, poet and punster Thomas Sheridan, a close friend of Swift and his collaborator on the Intelligencer in 1728-29. 1719 was the year that Sheridan published his spoof treatise, Ars Pun-ica, sive Flos Linguarum: The Art of Punning; or the Flower of Languages under the name Tom Pun-sibi. He was an unrepentant Tory and a high churchman. He also complained about English restrictions on

\footnotetext{
${ }^{101}$ It is quite typical of Swift that Some Considerations upon the Late Attempt uses the personal pronoun 'I' 37 times in a pamphlet of just over 4,000 words. There are paragraphs beginning 'Although I am ...', 'I suppose it will be allowed me...', 'Neither do I find ...', 'I could heartily wish ...', 'I have heard ...'. The Proposal for the Universal Use of Irish Manufacture is another striking example of this habit.

102 Swift to Tisdall, 3 Feb. 1704, Corr., I, 150-51.

103 See for example the plans made for the 'seventh' Drapier's letter, 'ready to be published upon the first day the Parliament meets', in Swift to John Worrall, 27 Aug. 1725, Corr., II, 591.

104 [Swift], Proposal for the Universal Use of Irish Manufacture, p. 7. The Drapier explained in his Letter to Viscount Molesworth that he had acquired his political opinions during his 'long Residence' in London: Davis, Drapier's Letters, p. 108.
} 
Irish trade and the promotion of Englishmen to Irish clerical positions. ${ }^{105} \mathrm{He}$ was capable of writing in the unstuffy style of the polite eighteenth-century periodical. Although he was not known as a political pamphleteer, four prose pieces on Wood's halfpence have been attributed to Sheridan: 106

Another Letter to Mr. Harding the Printer, Upon Occasion of the Report of the Committee of the Lords of His Majesty's most Honourable Privy-Council, in Relation to Mr. Wood's Half Pence and Farthings (Dublin, 1724);

The Present State of Ireland Consider'd: In a Letter to the Revd. Dean Swift. By a True Patriot ([Dublin], 1724);

The Fifth and Last Letter to the People of Ireland in reference to Wood and his Brass (Dublin, 1724);

Tom Punsibi’s Dream ([Dublin] 1725.

Only the last of these can be connected to Sheridan with any confidence, although the extremism of The Present State of Ireland Consider'd makes it entirely plausible that its author belonged to Swift's circle. Unlike the Drapier's Letters, however, there are no echoes in these works of Some Considerations upon the Last Attempt. Nor is it easy to imagine a scenario in which Sheridan, or the verbose Richard Helsham, or some other of the Dean's associates could have incorporated passages of Swift's manuscript writings into a composite work and then published it without his cooperation. ${ }^{107}$ The far simpler explanation is that the author was Swift himself.

\section{Significance}

It has always been assumed that Swift's return to Dublin was followed by six years of selfimposed silence broken only by the Proposal for the Universal Use of Irish Manufacture in May 1720. The relaunch of his career as a political propagandist has been attributed to a combination of Irish economic problems, the South Sea Bubble and above all the gestation of

105 Sir John Davies, Historical Relations: Or, A Discovery of the True Causes why Ireland was never Entirely Subdued, with a preface by Thomas Sheridan (Dublin, 1733), p. [iv].

106 Davis, Drapier's Letters, pp. xxxiii, 247-8; 358, 363, 368; Sabine Baltes-Ellermann, The Pamphlet Controversy about Wood's Halfpence (1722-25) and the Tradition of Irish Constitutional Nationalism (Frankfurt am Main, 2003), pp. 208-12, 231, 265-68, 278-9.

107 Some specialists have concluded that A Letter of Advice to a Young Poet, published by John Hyde in 1721, was an imitation of Swift's style by one of his close circle. It has been suggested that other disputed works may have originated with friends but incorporated Swiftian material. All of these works are literary essays or trifles rather than political polemic. See 'Appendix H: The Attribution to Swift of Letter of Advice to a Young Poet' in Valerie Rumbold (ed.), The Cambridge Works of Jonathan Swift, vol. II. Parodies, Hoaxes, Mock Treatises: 'Polite Conversation', 'Directions to Servants' and Other Works, (Cambridge, 2013). 
the Declaratory Act. 108 It is strange that Some Considerations upon the Late Attempt, which forces us to modify this view, has gone unnoticed for so long, given that Ehrenpreis, Landa and Fauske, among others, have studied the Wake correspondence carefully, and must have read Bishop Nicolson's letter describing a new pamphlet written by the Archbishop of Dublin 'or his Dean'.109 The identification of the Person of Quality prompts a new interpretation of Swift's political rebirth as the Hibernian Patriot, underlining the primacy and continuity of his fundamental commitment to the established Church of Ireland.

The political conjunction in 1719, brought about by the Whig schism two years before, and by the mishandling of Irish affairs by Sunderland and Stanhope, created an exciting opportunity for the rehabilitation of 'the church party'. A defining feature of the Stanhope-Sunderland ministry was its assault on clerical power within the British state or what John Toland called 'Protestant popery'. ${ }^{110}$ Its ecclesiastical posture was reflected in an infamous sermon preached by Benjamin Hoadly, the Bishop of Bangor, in the presence of George I, an event orchestrated by the Duke of Bolton just before he was appointed lord lieutenant of Ireland.111 Hoadly's The Nature of the Kingdom, or Church, of Christ (1717) defined the Christian church as an international community of sincere believers entitled to no political privileges. It provoked a pamphlet war that lasted for four years and amounted to 400 publications. In April 1719 Bolton likened Archbishop King of Dublin to Cardinal Alberoni, the Spanish minister behind the attempted Jacobite invasion of Scotland that spring. ${ }^{112}$ King meanwhile sneered that the Spanish expedition was 'the Invisible, as tother was called the Invincible Armada' - a remark that delighted Swift. ${ }^{113}$ Both knew that any new threat to the Protestant succession provided more ammunition for the Dissenters and their friends. ${ }^{114}$

In Ireland the parliamentary struggle was between the Brodrick faction and the speaker, William Conolly. It lacked the ideological dimension of the Whig schism at Westminster. But Conolly was regarded as consistently sympathetic to the Presbyterians. In the House of Commons St John Brodrick accused the speaker of acting as the ministry's 'undertaker' for the

108 David Nokes, Jonathan Swift: A Hypocrite Reversed (Oxford, 1985), pp. 265-66; Leo Damrosch, Jonathan Swift: His Life and His World (New Haven, 2013), pp. 338-42; John Stubbs, Jonathan Swift: The Reluctant Rebel (London, 2016), p. 432.

109 In a later letter a piqued Nicolson mentions that he has been mocked 'in a libellous Pamphlet' as 'one of $\mathrm{y}^{\mathrm{e}}$ Foreign Prelates, sent hither to Instruct and Civilise my Betters'. Nicolson to Wake, 17 Jan. 1720, Christ Church, Oxford, Wake MS XIII, 145.

110 [John Toland], The State-Anatomy of Great Britain (1717), ch. 7.

111 Andrew Starkie, The Church of England and the Bangorian Controversy 1716-1721 (Woodbridge, 2007), p. 28.

112 Ibid., p. 29.

113 Swift to Ford, 3 May 1719, Corr., II, 301.

114 Recall Swift's lines in 'Ireland': 'Our Letters say a Jesuite boasts/ Of some invasion on your coasts/ The King is ready when you will,/ To pass another Pop-ry bill/ And for dissenters he intends/ To use them as his truest friends': Harold Williams (ed.), The Poems of Jonathan Swift (3 vols., Oxford, 1958), II, 422. 
Dissenters bill, 'so destructive to the constitution'. While Midleton continued to defend English interests in the House of Lords, his son led a coalition in the Commons to oppose repeal with the 'Country Party \& many whom they had formerly ill used'. 115 As the Chief Secretary warned, the decision to raise the sacramental test would 'unite such a number of Whigs with the Tories as to give great perplexity'. ${ }^{116}$ The defeat of Upton's amendments by 200 votes to 20 showed the remarkable solidarity of MPs on this one issue. Evans was surprised to find 'so much spirit among $\mathrm{y}^{\mathrm{e}}$ honest [Church] \& country Patriots notwithstanding the large collections [of money] among the Sc[ots] Presbyterians'. ${ }^{117}$ In the subsequent Lords debate on toleration, however, the 'English' bishops - the most vocal defenders of the view that Ireland was 'a depending kingdom' - were marked out as the 'five Presbyterian prelates'.118

Following the death of Queen Anne, Swift had been denounced as a Jacobite in 'numberless libels' in England, while in Dublin he was 'insulted in the street, and at nights was forced to be attended by his servants armed'. ${ }^{119}$ For several years Archbishop King continued to keep him at arm's length. In 1716 Swift still felt marginalized at St Patrick's - out of favour with his archbishop, harassed by 'dormant prebends revived on purpose to oppose me', and stung by accusations that he had been complicit in the conspiracy to restore the Pretender. He protested to King that his connection with 'the late Ministry' was 'chiefly applied to do all the service to the Church that I was able'. ${ }^{120}$ The two men discussed the prospects for a reconciliation between the high-church clergy and the Hanoverian regime. Swift despaired that the Court, 'in the Midst of Strength and Security' would never stoop 'to cultivate the Dispositions of the People in the Dust'. ${ }^{121}$ King, on the other hand, believed the fault lay with the high churchmen. But Bolton's speech from the throne transformed the political landscape. By the end of 1719 Swift was regaling his old friend Charles Ford with the improbable news that the archbishop of Dublin was now 'half a Tory'. ${ }^{122}$ King would never have used these words himself. But the relationship between Swift and his archbishop, soured for so many years by the poison of party, had become warmer. In April 1720 Evans informed Wake that 'Dublin and his dean' were driving the agitation over the Declaratory Act; he made the same comment again three years

115 'Brief Account of Some Proceedings', 16 July 1719, Christ Church, Oxford, Wake MS XIII, 90.

116 Webster to Craggs, TNA SP 63/377, f. 226v.

117 Evans to Wake, 2 July 1719, Christ Church, Oxford, Wake MS XIII, 75.

118 Nicolson to Wake, 17 Oct. 1719, Christ Church, Oxford, Wake MS XIII,117; punctuation altered.

119 Jonathan Swift, The Complete Poems, ed. Pat Rogers (Harmondsworth, 1983), p. 855.

120 Swift to King, 17 June 1716, Corr., II, 167-68.

121 Swift to King, 13 Nov. 1716, Corr., II, 187.

122 Swift to Ford, 8 Dec. 1719, Corr., II, 311. 
later, adding that 'Both equally hate every thing called English'.123 The resistance to Wood's halfpence had just begun.

${ }^{123}$ Evans to Wake, 23 April 1720, 28 May 1723, Christ Church, Oxford, Wake MS XIII, 117 and XIV, 77. 